\title{
Asthma Programme in Finland: High consensus between general practitioners and pulmonologists on the contents of an asthma referral letter
}

\author{
Leena Tuomisto $^{a, *}$, Marina Erhola ${ }^{b, c}$, Minna Kaila ${ }^{\text {d,e }}$, Pirkko E. Brander ${ }^{f}$, \\ Hannu Puolijoki ${ }^{a}$, Ritva Kauppinen ${ }^{\text {, }}$, Kaj Koskela ${ }^{\text {b, }}$
}

${ }^{a}$ Central Hospital, Huhtalantie 53, 60220 Seinäjoki, Finland

${ }^{b}$ Finnish Lung Health Association, Finland

c Lammi-Tuulos Health Care Centre, Finland

d Current Care Guidelines, Finnish Medical Society Duodecim, Finland

e Pirkanmaa Hospital District, Department of General Practice, Finland

${ }^{\mathrm{f}}$ Hospital District of Helsinki and Uusimaa, Hyvinkää, Finland

${ }^{g}$ Centrat Hospital, Lappeenranta, Finland Received 9 January 2004; accepted 9 April 2004

KEYWORDS

Asthma;

Primary health care;

Referral letter;

Communication

\section{Summary}

Aims: The purpose of the present study was to define quality criteria for an asthma referral letter using a national co-operative effort between general practitioners and pulmonologists.

Methods: A consensus-seeking expert panel representing primary and secondary health care merged evidence from the literature and existing national and local asthma programmes to produce 19 provisional criteria to be included in an asthma referral letter. These criteria were contained within a national questionnaire review which was sent out to groups of Finnish physicians. The target groups for the review were all chief pulmonologists in specialist care $(n=32)$, and representatives of all Finnish health centres $(n=283)$ - either the chief physician $(n=143)$ or the local asthma co-ordinating physician $(n=140)$.

Results: The overall response rate to the national questionnaire study was $75 \%$. The three groups of responding physicians had very similar gradings on the necessity of the 19 provisional criteria, most of which were considered very necessary. 14 final disease-specific criteria for an asthma referral letter were derived as a result of this study.

Conclusion: The main result of this study is an agreed data set of essential information that needs to be included in an asthma referral letter. Importantly these criteria were developed by general practitioners and pulmonologists together.

(c) 2004 General Practice Airways Group. Published by Elsevier B.V. All rights reserved.

\footnotetext{
* Corresponding author. Fax: +358 64154989.

E-mail address: leena.tuomisto@epshp.fi (L. Tuomisto).

Deceased.
}

\section{Introduction}

Finland was one of the first countries where a $\mathrm{Na}$ tional Asthma Programme was launched in 1994 [1]. 
The main statements of the programme emphasised the role of primary health care in the prevention, diagnosis and long-term treatment of asthma. In order to optimise the management of asthma, measures to improve communication between health care professionals are needed.

A high-quality referral system is likely to contribute to the quality of care in different ways (a) by limiting over-medicalisation, over-investigation and over-treatment, (b) by permitting an appropriate division of tasks between generalists and many specialists, (c) by promoting technical progress by freeing specialists to develop their services further and (d) by ensuring economic progress by containing the costs of medical care [2]. It has been shown that the quality of the specialist consultation report improves in relation to the amount of referral information originally sent to the consultant [3].

Referral letters are an accessible, acceptable and objective source of information for evaluation of the communication between primary and secondary care [4]. In general, there is little information available on how evaluation criteria for referrals have been derived.

In Finland, there is a nationally endorsed structured referral letter form, which makes it easier to include information about the referring primary care physician (such as name and address), the patient (name, address, date of birth) and about the urgency when referring a patient. General quality criteria for Finnish referrals from general practice to secondary care were recently published $[5,6]$.

The aim of the present study was to derive evaluation criteria for a national adult patient's asthma referral letter. These criteria will be used in the ongoing evaluation of the Finnish Asthma Programme.

\section{Methods}

\section{Consensus-seeking expert panel}

The panel consisted of seven health professionals (Table 1). A modified Delphi technique was used to develop the evaluation criteria [7]. The panel merged evidence from the literature and existing national and local asthma programmes $[1,8-11]$ to produce provisional criteria for a review (Figure 1, Table 2).

\section{The national questionnaire review}

The provisional criteria were subjected to a national review. The reviewers included all Finnish chief pulmonologists in specialist care $(n=32)$,
Table 1 Members of the panel and their perspectives.

Pulmonologist, responsible researcher (LT)

Chief Physician in Primary Health Care, quality expert, representative of Finnish Lung Health Association (ME)

Chief Editor of National Current Care Guidelines, pathways of care (MK)

Chief Pulmonologist, regional pathways of care (PB)

Hospital District Chief Physician, administrative (RK)

Hospital District Chief Physician, management of asthma (HP)

Professor, implementation of guidelines, representative of Finnish Lung Health Association (KK)

and representatives of all Finnish health centres $(n=283)$ - either the chief physician $(n=143)$ or the local asthma co-ordinating physician $(n=140)$. The reviewers were asked to grade the necessity of each of the 19 suggested criteria (Table 3 ) as being very necessary, necessary, or unnecessary. The national questionnaire survey was mailed in June 2001, followed by a reminder in August 2001.

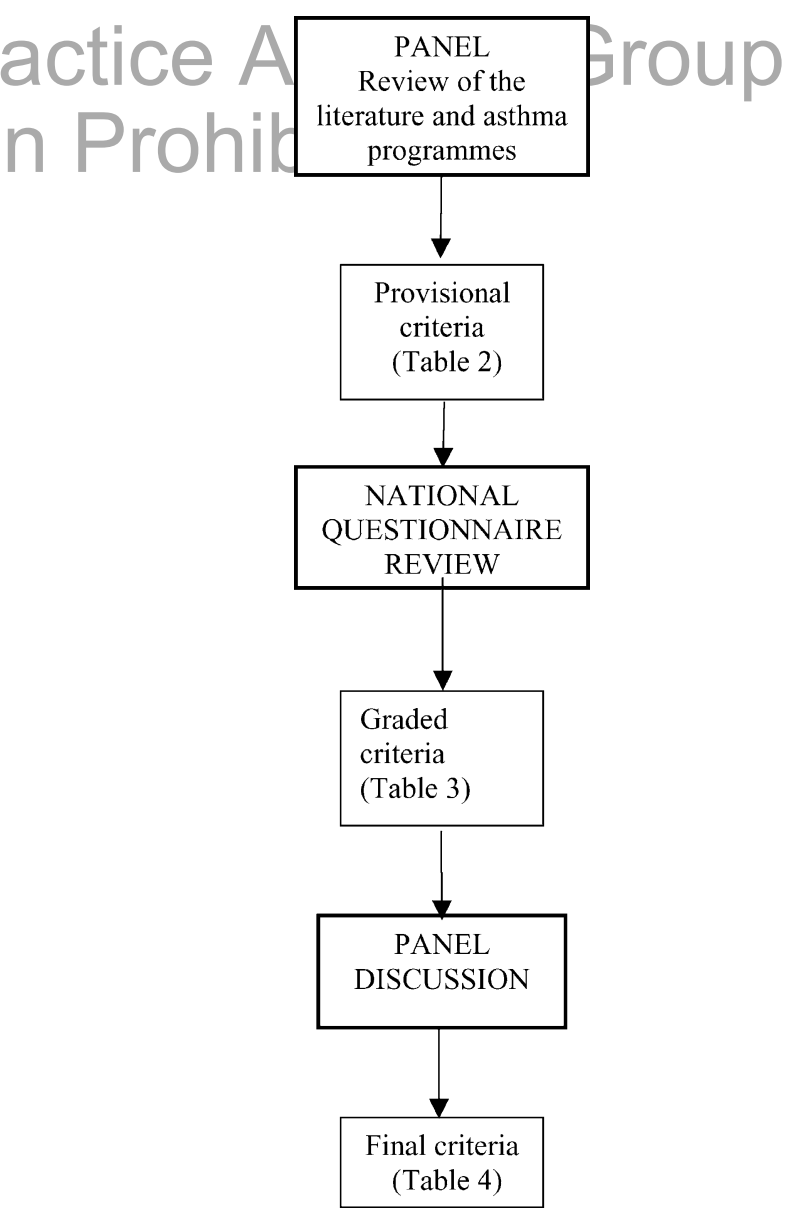

Figure 1 General outline of the study. 
Table 2 Provisional criteria for asthma referral letter.

Family history

Occupation

Onset of the symptoms

Dyspnoea

Specified dyspnoea

Cough

Specified cough

Wheezing

Smoking

Known allergies

Cardiorespiratory status

Peak flow-follow up

Spirometry and bronchodilatation test

Thorax X-ray

Nasal sinus X-ray

Blood eosinophils

Use of asthma medication

Other diseases

Other current medication

\section{Statistical analysis}

The proportion of the "'very necessary' gradings for each of the provisional criteria was calculated separately for the three groups of physicians, and the differences between them were analyzed by means of the chi-square test. In a case of a $p$-value less than 0.10 , a post hoc analysis was performed and the chief pulmonologists were compared to other physicians. The categories for the provisional criteria were coded as follows: very necessary $=2$, necessary $=1$ and unnecessary $=0$. The sums of the codes for different criteria groups were calculated, indicating the overall assessment of necessity. For all the criteria the possible range was 0-38. Analysis of variance (ANOVA) was used to compare the sums of codes between physician groups. Fisher's LSD test was used for paired comparisons. The data were analysed by means of SPSS (Version 10.1).

\section{Results}

The overall response rate in the national review after two inquiries was $75 \%$; $91 \%$ of the chief pulmonologists, $77 \%$ of the chief physicians and $71 \%$ of the local asthma co-ordinator physicians in primary health care responded. There was a difference between the response rates in the three groups of physicians ( $p=0.054$, Chi-Square test). The difference was significant when the chief pulmonologists were compared to the other physicians ( $91 \%$ vs
$74 \%, p=0.036$, Chi-Square test). The three groups of physicians graded the criteria similarly. Most of the provisional criteria were considered very necessary (Table 3 ). The chief pulmonologists considered all criteria more necessary than the other groups, but the difference between the groups did not manifest statistical significance $(p=0.24)$. The mean necessary scores were 40.0 (SD 6.1), 38.3 (6.5) and 37.7 (6.4) for chief pulmonologists, local asthma co-ordinator physicians and chief general physicians, respectively.

All provisional criteria considered very necessary for an asthma referral letter by more than $50 \%$ of the respondents were included in the final list. The expert panel included one additional criterion: spirometry and bronchodilatation test. The final set of criteria included 14 asthma-specific patient-related criteria (Table 4).

\section{Discussion}

According to previous studies criteria to be used in health evaluation should (a) be based on evidence, (b) be prioritized according to the strength of research evidence and influence on outcome, (c) be clearly and precisely measurable and (d)be appropriate for the clinical setting [12,13]. The consensus-seeking expertpanel worked to ensure that the final patient-related asthma referral criteria complied with these requirements. The specific task of the panel was to assess and interpret the literature, and international and regional guidelines, as well as the results of the national questionnaire review.

There are different methods by which consensus on the development of quality criteria can be attained in situations when evidence is insufficient. Methods used in health care research are: the Delphi process, the nominal group (expert panel) technique, and the RAND appropriateness method [7]. Variations of these methods have been used in order to adapt the method to the problem instead of adapting the problem to the method [14]. The study group chose a method whereby expert panel discussions and the national survey of both primary and secondary care physicians played a major role. General practitioners and pulmonologists should have a common view of the essential components of an asthma referral letter. Patient participation was not considered, since the main goal of the study was to keep the design simple, i.e. to evaluate communication between these two groups of physicians in the context of the National Asthma Programme. However, surveying patient and (for example) asthma nurse opinions on the 14 devel- 
Table 3 Gradings of the asthma referral letter criteria between the three groups of physicians (score $2=$ very necessary, score $1=$ necessary, score $0=$ unnecessary).

\begin{tabular}{|c|c|c|c|c|c|c|c|c|c|c|c|}
\hline \multirow[b]{2}{*}{1.} & \multirow{2}{*}{$\begin{array}{l}\text { Asthma referral } \\
\text { letter criteria }\end{array}$} & \multirow{2}{*}{$\begin{array}{l}\text { Score } \\
2 \\
1 \\
0 \\
\text { Total }\end{array}$} & \multicolumn{2}{|c|}{$\begin{array}{l}\text { Chief } \\
\text { pulmonologistics }\end{array}$} & \multicolumn{2}{|c|}{$\begin{array}{l}\text { Local asthma } \\
\text { co-ordinator } \\
\text { physicians }\end{array}$} & \multicolumn{2}{|c|}{$\begin{array}{l}\text { Chief general } \\
\text { physicians }\end{array}$} & \multicolumn{2}{|c|}{ Total } & \multirow{2}{*}{$\begin{array}{l}p \text {-value } \\
0.088 \\
(0.036)\end{array}$} \\
\hline & & & $\begin{array}{l}11 \\
17 \\
0 \\
28\end{array}$ & $\begin{array}{l}39,3 \% \\
60,7 \% \\
100,0 \%\end{array}$ & $\begin{array}{l}23 \\
71 \\
4 \\
98\end{array}$ & $\begin{array}{l}23,5 \% \\
72,4 \% \\
4,1 \% \\
100,0 \%\end{array}$ & $\begin{array}{l}21 \\
82 \\
5 \\
108\end{array}$ & $\begin{array}{l}19,4 \% \\
75,9 \% \\
4,6 \% \\
100,0 \%\end{array}$ & $\begin{array}{l}55 \\
170 \\
9 \\
234\end{array}$ & $\begin{array}{l}23,5 \% \\
72,6 \% \\
3,8 \% \\
100,0 \%\end{array}$ & \\
\hline 2. & Occupation & $\begin{array}{l}2 \\
1 \\
0 \\
\text { Total }\end{array}$ & $\begin{array}{l}18 \\
11 \\
0 \\
29\end{array}$ & $\begin{array}{l}62,1 \% \\
37,9 \% \\
\\
100,0 \%\end{array}$ & $\begin{array}{l}47 \\
50 \\
1 \\
98\end{array}$ & $\begin{array}{l}48,0 \% \\
51,0 \% \\
1,0 \% \\
100,0 \%\end{array}$ & $\begin{array}{l}53 \\
55 \\
1 \\
109\end{array}$ & $\begin{array}{l}48,6 \% \\
50,5 \% \\
, 9 \% \\
100,0 \%\end{array}$ & $\begin{array}{l}118 \\
116 \\
2 \\
236\end{array}$ & $\begin{array}{l}50,0 \% \\
49,2 \% \\
, 8 \% \\
100,0 \%\end{array}$ & 0.38 \\
\hline 3. & $\begin{array}{l}\text { Onset of the } \\
\text { symptoms }\end{array}$ & $\begin{array}{l}2 \\
1 \\
\text { Total }\end{array}$ & $\begin{array}{l}23 \\
6 \\
29\end{array}$ & $\begin{array}{l}79,3 \% \\
20,7 \% \\
100,0 \%\end{array}$ & $\begin{array}{l}70 \\
29 \\
99\end{array}$ & $\begin{array}{l}70,7 \% \\
29,3 \% \\
100,0 \%\end{array}$ & $\begin{array}{l}74 \\
35 \\
109\end{array}$ & $\begin{array}{l}67,9 \% \\
32,1 \% \\
100,0 \%\end{array}$ & $\begin{array}{l}167 \\
70 \\
237\end{array}$ & $\begin{array}{l}70,5 \% \\
29,5 \% \\
100,0 \%\end{array}$ & 0.49 \\
\hline 4. & Dyspnoea & $\begin{array}{l}2 \\
1 \\
0 \\
\text { Total }\end{array}$ & $\begin{array}{l}23 \\
6 \\
0 \\
29\end{array}$ & $\begin{array}{l}79,3 \% \\
20,7 \% \\
\\
100,0 \%\end{array}$ & $\begin{array}{l}73 \\
23 \\
2 \\
98\end{array}$ & $\begin{array}{l}74,5 \% \\
23,5 \% \\
2,0 \% \\
100,0 \%\end{array}$ & $\begin{array}{l}79 \\
28 \\
1 \\
108\end{array}$ & $\begin{array}{l}73,1 \% \\
25,9 \% \\
, 9 \% \\
100,0 \%\end{array}$ & $\begin{array}{l}175 \\
57 \\
3 \\
235\end{array}$ & $\begin{array}{l}74,5 \% \\
24,3 \% \\
1,3 \% \\
100,0 \%\end{array}$ & 0.80 \\
\hline 5. & $\begin{array}{l}\text { Specified } \\
\text { dyspnoea }\end{array}$ & $\begin{array}{l}2 \\
1 \\
\text { Total }\end{array}$ & $\begin{array}{l}17 \\
12 \\
29\end{array}$ & $\begin{array}{l}58,6 \% \\
41,4 \% \\
100,0 \%\end{array}$ & $\begin{array}{l}71 \\
28 \\
99\end{array}$ & $\begin{array}{l}71,7 \% \\
28,3 \% \\
100,0 \%\end{array}$ & $\begin{array}{l}74 \\
35 \\
109\end{array}$ & $\begin{array}{l}67,9 \% \\
32,1 \% \\
100,0 \%\end{array}$ & $\begin{array}{l}162 \\
75 \\
237\end{array}$ & $\begin{array}{l}68,4 \% \\
31,6 \% \\
100,0 \%\end{array}$ & 0.41 \\
\hline 6. & Cough & $\begin{array}{l}2 \\
1 \\
0 \\
\text { Total }\end{array}$ & $\begin{array}{l}20 \\
9 \\
0 \\
29\end{array}$ & $\begin{array}{l}69,0 \% \\
31,0 \% \\
100,0 \%\end{array}$ & $\begin{array}{l}61 \\
36 \\
1 \\
98\end{array}$ & $\begin{array}{l}62,2 \% \\
36,7 \% \\
1,0 \% \\
100,0 \%\end{array}$ & $\begin{array}{l}55 \\
52 \\
2 \\
109\end{array}$ & $\begin{array}{l}50,5 \% \\
47,7 \% \\
1,8 \% \\
100,0 \%\end{array}$ & $\begin{array}{l}136 \\
97 \\
3 \\
236\end{array}$ & $\begin{array}{l}57,6 \% \\
41,1 \% \\
1,3 \% \\
100,0 \%\end{array}$ & $\begin{array}{l}0.096 \\
(0.187)\end{array}$ \\
\hline 7. & Specified cough & $\begin{array}{l}2 \\
1 \\
0 \\
\text { Total }\end{array}$ & $\begin{array}{l}16 \\
13 \\
0 \\
29\end{array}$ & $\begin{array}{l}55,2 \% \\
44,8 \% \\
\\
100,0 \%\end{array}$ & $\begin{array}{l}61 \\
35 \\
2 \\
98\end{array}$ & $\begin{array}{l}62,2 \% \\
35,7 \% \\
2,0 \% \\
100,0 \%\end{array}$ & $\begin{array}{l}50 \\
57 \\
2 \\
109\end{array}$ & $\begin{array}{l}45,9 \% \\
52,3 \% \\
1,8 \% \\
100,0 \%\end{array}$ & $\begin{array}{l}127 \\
105 \\
4 \\
236\end{array}$ & $\begin{array}{l}53,8 \% \\
44,5 \% \\
1,7 \% \\
100,0 \%\end{array}$ & $\begin{array}{l}0.061 \\
(0.875)\end{array}$ \\
\hline 8. & Wheezing & $\begin{array}{l}2 \\
1 \\
0 \\
\text { Total }\end{array}$ & $\begin{array}{l}20 \\
9 \\
0 \\
29\end{array}$ & $\begin{array}{c}69,0 \% \\
31,0 \% \\
100,0 \%\end{array}$ & $\begin{array}{l}71 \\
26 \\
0 \\
97\end{array}$ & $\begin{array}{l}73,2 \% \\
26,8 \% \\
\\
100,0 \%\end{array}$ & $\begin{array}{l}71 \\
37 \\
1 \\
109\end{array}$ & $\begin{array}{l}65,1 \% \\
33,9 \% \\
, 9 \% \\
100,0 \%\end{array}$ & $\begin{array}{l}162 \\
72 \\
1 \\
235\end{array}$ & $\begin{array}{l}68,9 \% \\
30,6 \% \\
, 4 \% \\
100,0 \%\end{array}$ & 0.46 \\
\hline 9. & Smoking & $\begin{array}{l}2 \\
1 \\
0 \\
\text { Total }\end{array}$ & $\begin{array}{l}27 \\
2 \\
0 \\
29\end{array}$ & $\begin{array}{l}93,1 \% \\
6,9 \% \\
100,0 \%\end{array}$ & $\begin{array}{l}79 \\
20 \\
0 \\
99\end{array}$ & $\begin{array}{l}79,8 \% \\
20,2 \% \\
\\
100,0 \%\end{array}$ & $\begin{array}{l}81 \\
27 \\
1 \\
109\end{array}$ & $\begin{array}{l}74,3 \% \\
24,8 \% \\
, 9 \% \\
100,0 \%\end{array}$ & $\begin{array}{l}187 \\
49 \\
1 \\
237\end{array}$ & $\begin{array}{l}78,9 \% \\
20,7 \% \\
, 4 \% \\
100,0 \%\end{array}$ & $\begin{array}{l}0.085 \\
(0.045)\end{array}$ \\
\hline 10. & Known allergies & $\begin{array}{l}2 \\
1 \\
0 \\
\text { Total }\end{array}$ & $\begin{array}{l}15 \\
13 \\
1 \\
29\end{array}$ & $\begin{array}{l}51,7 \% \\
44,8 \% \\
3,4 \% \\
100,0 \%\end{array}$ & $\begin{array}{l}65 \\
34 \\
0 \\
99\end{array}$ & $\begin{array}{l}65,7 \% \\
34,3 \% \\
100,0 \%\end{array}$ & $\begin{array}{l}63 \\
46 \\
0 \\
109\end{array}$ & $\begin{array}{l}57,8 \% \\
42,2 \% \\
100,0 \%\end{array}$ & $\begin{array}{l}143 \\
93 \\
1 \\
237\end{array}$ & $\begin{array}{l}60,3 \% \\
39,2 \% \\
, 4 \% \\
100,0 \%\end{array}$ & 0.61 \\
\hline 11. & $\begin{array}{l}\text { Cardiorespiratoy } \\
\text { status }\end{array}$ & $\begin{array}{l}2 \\
1 \\
0 \\
\text { Total }\end{array}$ & $\begin{array}{l}13 \\
15 \\
1 \\
29\end{array}$ & $\begin{array}{l}44,8 \% \\
51,7 \% \\
3,4 \% \\
100,0 \%\end{array}$ & $\begin{array}{l}48 \\
48 \\
3 \\
99\end{array}$ & $\begin{array}{l}48,5 \% \\
48,5 \% \\
3,0 \% \\
100,0 \%\end{array}$ & $\begin{array}{l}49 \\
59 \\
2 \\
110\end{array}$ & $\begin{array}{l}44,5 \% \\
53,6 \% \\
1,8 \% \\
100,0 \%\end{array}$ & $\begin{array}{l}110 \\
122 \\
6 \\
238\end{array}$ & $\begin{array}{l}46,2 \% \\
51,3 \% \\
2,5 \% \\
100,0 \%\end{array}$ & 0.84 \\
\hline 12. & $\begin{array}{l}\text { Peak Flow-follow } \\
\text { up }\end{array}$ & $\begin{array}{l}2 \\
1 \\
0 \\
\text { Total }\end{array}$ & $\begin{array}{l}17 \\
12 \\
0 \\
29\end{array}$ & $\begin{array}{r}58,6 \% \\
41,4 \% \\
100,0 \%\end{array}$ & $\begin{array}{l}54 \\
44 \\
1 \\
99\end{array}$ & $\begin{array}{l}54,5 \% \\
44,4 \% \\
1,0 \% \\
100,0 \%\end{array}$ & $\begin{array}{l}56 \\
50 \\
3 \\
109\end{array}$ & $\begin{array}{l}51,4 \% \\
45,9 \% \\
2,8 \% \\
100,0 \%\end{array}$ & $\begin{array}{l}127 \\
106 \\
4 \\
237\end{array}$ & $\begin{array}{l}53,6 \% \\
44,7 \% \\
1,7 \% \\
100,0 \%\end{array}$ & 0.76 \\
\hline
\end{tabular}


Table 3 (Continued)

\begin{tabular}{|c|c|c|c|c|c|c|c|c|c|c|c|}
\hline \multirow{3}{*}{$\frac{}{13 .}$} & \multirow{3}{*}{$\begin{array}{l}\text { Asthma referral } \\
\text { letter criteria } \\
\text { Spirometry and } \\
\text { bronchodilation } \\
\text { test }\end{array}$} & \multirow{2}{*}{$\begin{array}{l}\text { Score } \\
2\end{array}$} & \multicolumn{2}{|c|}{$\begin{array}{l}\text { Chief } \\
\text { pulmonologistics }\end{array}$} & \multicolumn{2}{|c|}{$\begin{array}{l}\text { Local asthma } \\
\text { co-ordinator } \\
\text { physicians }\end{array}$} & \multicolumn{2}{|c|}{$\begin{array}{l}\text { Chief general } \\
\text { physicians }\end{array}$} & \multicolumn{2}{|l|}{ Total } & \multirow{3}{*}{$\begin{array}{l}p \text {-value }{ }^{\mathrm{a}} \\
0.99\end{array}$} \\
\hline & & & 11 & $37,9 \%$ & 36 & $36,7 \%$ & 41 & $37,6 \%$ & 88 & $37,3 \%$ & \\
\hline & & $\begin{array}{l}1 \\
0 \\
\text { Total }\end{array}$ & $\begin{array}{l}18 \\
0 \\
29\end{array}$ & $\begin{array}{l}62,1 \% \\
100,0 \%\end{array}$ & $\begin{array}{l}55 \\
7 \\
98\end{array}$ & $\begin{array}{l}56,1 \% \\
7,1 \% \\
100,0 \%\end{array}$ & $\begin{array}{l}63 \\
5 \\
109\end{array}$ & $\begin{array}{l}57,8 \% \\
4,6 \% \\
100,0 \%\end{array}$ & $\begin{array}{l}136 \\
12 \\
236\end{array}$ & $\begin{array}{l}57,6 \% \\
5,1 \% \\
100,0 \%\end{array}$ & \\
\hline 14. & Thorax X-ray & $\begin{array}{l}2 \\
1 \\
0 \\
\text { Total }\end{array}$ & $\begin{array}{l}17 \\
12 \\
0 \\
29\end{array}$ & $\begin{array}{l}58,6 \% \\
41,4 \% \\
\\
100,0 \%\end{array}$ & $\begin{array}{l}39 \\
56 \\
4 \\
99\end{array}$ & $\begin{array}{l}39,4 \% \\
56,6 \% \\
4,0 \% \\
100,0 \%\end{array}$ & $\begin{array}{l}42 \\
65 \\
2 \\
109\end{array}$ & $\begin{array}{l}38,5 \% \\
59,6 \% \\
1,8 \% \\
100,0 \%\end{array}$ & $\begin{array}{l}98 \\
133 \\
6 \\
237\end{array}$ & $\begin{array}{l}41,4 \% \\
56,1 \% \\
2,5 \% \\
100,0 \%\end{array}$ & 0.13 \\
\hline 15. & Nasal sinus X-ray & $\begin{array}{l}2 \\
1 \\
0 \\
\text { Total }\end{array}$ & $\begin{array}{l}8 \\
21 \\
0 \\
29\end{array}$ & $\begin{array}{l}27,6 \% \\
72,4 \% \\
\\
100,0 \%\end{array}$ & $\begin{array}{l}20 \\
67 \\
11 \\
98\end{array}$ & $\begin{array}{l}20,4 \% \\
68,4 \% \\
11,2 \% \\
100,0 \%\end{array}$ & $\begin{array}{l}15 \\
81 \\
13 \\
109\end{array}$ & $\begin{array}{l}13,8 \% \\
74,3 \% \\
11,9 \% \\
100,0 \%\end{array}$ & $\begin{array}{l}43 \\
169 \\
24 \\
236\end{array}$ & $\begin{array}{l}18,2 \% \\
71,6 \% \\
10,2 \% \\
100,0 \%\end{array}$ & 0.18 \\
\hline 16. & Blood eosinophils & $\begin{array}{l}2 \\
1 \\
0 \\
\text { Total }\end{array}$ & $\begin{array}{l}5 \\
20 \\
3 \\
28\end{array}$ & $\begin{array}{l}17,9 \% \\
71,4 \% \\
10,7 \% \\
100,0 \%\end{array}$ & $\begin{array}{l}15 \\
62 \\
22 \\
99\end{array}$ & $\begin{array}{l}15,2 \% \\
62,6 \% \\
22,2 \% \\
100,0 \%\end{array}$ & $\begin{array}{l}18 \\
65 \\
26 \\
109\end{array}$ & $\begin{array}{l}16,5 \% \\
59,6 \% \\
23,9 \% \\
100,0 \%\end{array}$ & $\begin{array}{l}38 \\
147 \\
51 \\
236\end{array}$ & $\begin{array}{l}16,1 \% \\
62,3 \% \\
21,6 \% \\
100,0 \%\end{array}$ & 0.93 \\
\hline 17. & $\begin{array}{l}\text { Use of asthma } \\
\text { medication }\end{array}$ & $\begin{array}{l}2 \\
1 \\
0 \\
\text { Total }\end{array}$ & $\begin{array}{l}19 \\
10 \\
0 \\
29\end{array}$ & $\begin{array}{l}65,5 \% \\
34,5 \% \\
\\
100,0 \%\end{array}$ & $\begin{array}{l}66 \\
32 \\
1 \\
99\end{array}$ & $\begin{array}{l}66,7 \% \\
32,3 \% \\
1,0 \% \\
100,0 \%\end{array}$ & $\begin{array}{l}59 \\
51 \\
0 \\
110\end{array}$ & $\begin{array}{l}53,6 \% \\
46,4 \% \\
\\
100,0 \%\end{array}$ & $\begin{array}{l}144 \\
93 \\
1 \\
238\end{array}$ & $\begin{array}{l}60,5 \% \\
39,1 \% \\
, 4 \% \\
100,0 \%\end{array}$ & 0.13 \\
\hline 18. & Other diseases & $\begin{array}{l}2 \\
1 \\
\text { Total }\end{array}$ & $\begin{array}{l}16 \\
13 \\
29\end{array}$ & $\begin{array}{l}55,2 \% \\
44,8 \% \\
100,0 \%\end{array}$ & $\begin{array}{l}49 \\
50 \\
99\end{array}$ & $\begin{array}{l}49,5 \% \\
50,5 \% \\
100,0 \%\end{array}$ & $\begin{array}{l}56 \\
54 \\
110\end{array}$ & $\begin{array}{l}50,9 \% \\
49,1 \% \\
100,0 \%\end{array}$ & $\begin{array}{l}121 \\
117 \\
238\end{array}$ & $\begin{array}{l}50,8 \% \\
49,2 \% \\
100,0 \%\end{array}$ & 0.87 \\
\hline 19. & $\begin{array}{l}\text { Other current } \\
\text { medication }\end{array}$ & $\begin{array}{l}2 \\
1 \\
\text { Total }\end{array}$ & $\begin{array}{l}14 \\
15 \\
29\end{array}$ & $\begin{array}{l}48,3 \% \\
51,7 \% \\
100,0 \%\end{array}$ & $\begin{array}{l}54 \\
45 \\
99\end{array}$ & $\begin{array}{l}54,5 \% \\
45,5 \% \\
100,0 \%\end{array}$ & $\begin{array}{l}62 \\
48 \\
110\end{array}$ & $\begin{array}{l}56,4 \% \\
43,6 \% \\
100,0 \%\end{array}$ & $\begin{array}{l}130 \\
108 \\
238\end{array}$ & $\begin{array}{l}54,6 \% \\
45,4 \% \\
100,0 \%\end{array}$ & 0.74 \\
\hline
\end{tabular}

a Comparing the three physician groups with respect to the proportion of the category of 'very necessary' = score

2 (Chi-square test). Comparison between chief pulmonologists vs all others is in brackets.

oped criteria might give additional insight into the process.

In the national questionnaire, 315 physicians in total (general practitioners and chief pulmonologists) were asked to grade and comment on the 19 criteria we had proposed. The total response rate was good (75\%). Differences between the groups were much smaller than we expected, which suggests that there exists a national consensus on the main features of the management of asthma. This could result from the previous intensive educational effort of the National Asthma Programme, with 25000 health professionals trained [15].

A criterion assessed in the national questionnaire was included in the final set if more than half of the respondents considered it very necessary. Spirometry and bronchodilatation test did not reach this threshold. However, the panel decided to include this criterion in the final list because, according to
Table 4 Final criteria for asthma referral letter.

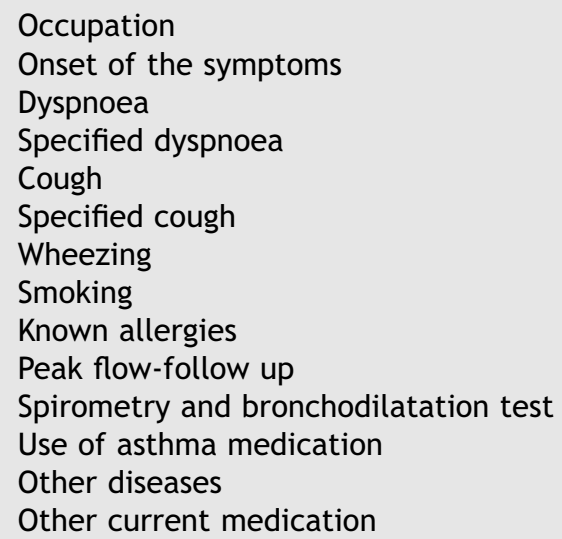


our recent study, there are facilities for spirometry measurement in $95 \%$ of the health centres in Finland [16]. History-taking is always the main source of facts on which a diagnosis of asthma is based. However, as the National Asthma Programme recommends, lung function measurements should be a fundamental part of asthma management in primary health care. Measuring lung function adds a more objective set of data when considering the diagnosis of asthma in a given patient.

The development of audit criteria is only the first step in the audit cycle [17]. The main result of this study is an agreed data set on information that needs to be included in an asthma referral letter. The 14 patient-related disease-specific criteria ensure that important diagnostic and management steps related to this respiratory problem are summarized in the referral text. Although doctors may still hesitate to follow very strict standards of communication [18] the good response rate in the present study indicates willingness to participate in quality improvement efforts.

Whether we actually have succeeded in developing applicable criteria for asthma referral letters will only be proved once they have been used in an audit. Such a national evaluation study is currently in process. yright General Pra

\section{Acknowledgements}

We are grateful to Professor Pertti Kekki, who taught us systematically methods for assessing quality in health care. We would also like to thank Viveca Bergman, Tuija Poussa, and all the respondents of our questionnaire. The support of the Finnish Lung and Health Association and the Finnish Anti-Tuberculosis Association Foundation is gratefully acknowledged.

\section{References}

[1] Asthma Programme in Finland 1994-2004. Clin Exp Allergy 1996;26(Suppl 1):1-24.
[2] Marinker M. The referral system. J Roy Coll Gen Pract 1988;38:487-91.

[3] Hansen JP, Brown SE, Sullivan Jr RJ, Muhlbaier LH. Factors related to an effective referral and consultation process. J Fam Pract 1982;15(4):651-6.

[4] Montalto M. Using referral letters to measure quality and performance in general practice. J Qual Clin Practice 1995;15:45-50.

[5] Latva-Nevala A, Särmö A, Leisti S. The quality of referral and consultation (in Finnish). Etelä-Pohjanmaan malli, julkaisu 9. Etelä-Pohjanmaan sairaanhoitopiiri 1995.

[6] Ketola E, Mäkelä J, Hagman E, Kupiainen Outi. General practitioners consulting in Helsinki (in Finnish). Finn Med J 2001;56:1297-1301.

[7] Campbell SM, Branspenning J, Hutchinson A, Marshall M. Research methods used in developing and applying quality indicators in primary care. Qual Saf Health Care 2002;11(4):358-64.

[8] NHLBI/WHO. Global strategy for asthma management and prevention. NHLBI/WHO Workshop Report. US National Heart, Lung and Blood Institute and the World Health Organisation, 1995.

[9] Report: Nordic consensus report on asthma management. Respir Med 2000;94:299-327.

[10] British Asthma Guidelines Coordination Committee. British guidelines on asthma management. Thorax 1997;52:124.

[11] Haahtela T, Kaila M, Ahonen E, Kava T, Kinnula V, Klaukka T, et al. Current Care Guideline for Asthma (in Finnish). Duodecim 2000;116:2568-84.

[12] Baker R, Fraser R. Fortnightly Review: Development of re- view criteria: linking guidelines and assessment of quality. BMJ 1995;311:370-3.

[13] Hearnshaw $\| H M$, "Harker $R M$, Cheater FM, Baker $R H$, Grimshaw GM. Are atudits wasting resources by measuring the wrong things? A survey of methods used to select audit review criteria. Qual Saf Health Care 2003;12:248.

[14] Linstone HA. The Delphi technique Handbook of futures research, Greenwood Press, Westport, CT, 1978.

[15] Haahtela T, Klaukka T, Koskela K, Erhola M, Laitinen LA. Asthma Programme in Finland: a community problem needs community solution. Thorax 2001;56:806-14.

[16] Erhola M, Makinen R, Koskela K, Bergman V, Klaukka T, Makela $M$, et al. The Asthma Programme of Finland: an evaluation survey in primary health care. Int J Tuberc Lung Dis 2003;7(6):592-8.

[17] Ovretveit J. Evaluating Health Interventions. Buckingham, Philadelphia: Open University Press 1999.

[18] Newton J, Eccles M, Hutchinson A. Communication between general practitioners and consultants: what should their letters contain? BMJ 1992;304:821-4.

Available online at www.sciencedirect.com

science $\boldsymbol{d}$ Directo

Available online at http://www.thepcrj.com 